\title{
Geographical differences in organochlorine contaminants in harbour porpoises Phocoena phocoena from the western North Atlantic
}

\author{
Andrew J. Westgate ${ }^{1, *}$, Krystal A. Tolley ${ }^{2}$ \\ ${ }^{1}$ Duke University Marine Lab, 135 Duke Marine Lab Road, Beaufort, North Carolina 28516, USA \\ ${ }^{2}$ Institute of Marine Research, Marine Mammal Division, PO Box 1870 Nordnes, N-5024 Bergen, Norway
}

\begin{abstract}
Organochlorine contaminants, including polychlorinated biphenyls (PCBs), chlorinated bornanes (CHBs), dichloro-diphenyl-trichloroethanes (DDTs), chlordanes (CHLORs), hexachlorocyclohexanes (HCHs) and, chlorobenzenes (CBZs) were quantified in 188 harbour porpoises (Phocoena phocoena) killed in commercial fisheries in the coastal waters of the Avalon Peninsula, Newfoundland $(n=$ 29), the Gaspé Peninsula, Quebec (Gulf of St. Lawrence) $(n=58)$, Grand Manan Island, New Brunswick (Bay of Fundy) ( $\mathrm{n}=86$ ), and Jeffreys Ledge in the Gulf of Maine ( $\mathrm{n}=15$ ). Levels were compared to determine if there were systematic differences in the organochlorine (OC) contaminant composition of harbour porpoises from these areas (Newfoundland, St. Lawrence, Bay of Fundy-Gulf of Maine) in the western North Atlantic. Bivariate analyses run on all 188 individuals showed both Fundy-Maine and St. Lawrence males had significantly higher levels of CHLORs, DDTs, PCBs and CHBs than Newfoundland males. Fundy-Maine males also had significantly higher levels of CHLORs and PCBs than those from the St. Lawrence and St. Lawrence males had significantly higher levels of HCHs than males from Fundy-Maine. Females from Fundy-Maine had significantly higher levels of total PCB than both St. Lawrence and Newfoundland females. Total DDT levels were significantly higher in FundyMaine and St. Lawrence females than those from Newfoundland. Total CHLOR values were significantly higher in Fundy-Maine than in Newfoundland females. Multivariate analysis, run on a subset consisting of 100 immature harbour porpoises showed significant differences among the group centroids on both discriminant functions (Wilks' Lambda $p<0.001$ ) demonstrating that these geographic groups are distinguishable based on $\mathrm{OC}$ levels. These results indicate that delineating the western North Atlantic harbour porpoise population into sub-populations defined as Newfoundland, Gulf of St. Lawrence and Bay of Fundy-Gulf of Maine is appropriate.
\end{abstract}

KEY WORDS: Harbour porpoise - Organochlorine contaminants - Population structure - Western North Atlantic

\section{INTRODUCTION}

Throughout their range, harbour porpoises Phocoena phocoena are vulnerable to incidental mortality in gill nets (Jefferson \& Curry 1994). Recent estimates of the numbers of harbour porpoises killed in Canadian and American commercial fishing operations (Lien 1987. Fontaine et al. 1994a, Bravington \& Bisack 1996, Trippel et al. 1996), together with the limited potential

\footnotetext{
•E-mail: westgate@acub.duke.edu
}

of the species to withstand such mortality (Woodley \& Read 1991) have raised concern over the status of this species in the North Atlantic. For example, the Committee on the Status of Endangered Wildlife in Canada considers western Atlantic harbour porpoises as threatened (Gaskin 1992). The high level of incidental mortality also prompted the Scientific Committee of the International Whaling Commission (IWC) to recommend that the population structure of harbour porpoises in the North Atlantic be identified (IWC 1994). The IWC recommended that an integrated approach should be developed that could examine information 
on both evolutionary (genetics, morphology) and ecological (chemical indicators, life histories) time scales.

Identifying the population structure of a species is a critical step in the development of management and conservation strategies (Dizon et al. 1992). Gaskin (1984) suggested there were 4 harbour porpoise subpopulations in the western North Atlantic: Greenland (western and southeastern), Newfoundland-Labrador, Gulf of St. Lawrence, and Bay of Fundy-Gulf of Maine. This proposed sub-population structure was based on evidence from morphology, seasonal movements, the timing and distribution of sightings, strandings, and incidental catches. In a recent analysis of harbour porpoise mitochondrial DNA from the latter 3 sub-populations, Wang et al. (1996) concluded there was genetic support for this putative population structure, prompting the IWC to provisionally accept this structure as a working hypothesis

Attempts have been made to use differences in the ratios and compositions of various organochlorine (OC) pollutants to evaluate population identity and discreteness in marine mammals (Calambokidis 1986, Muir et al. 1990, Calambokidis \& Barlow 1991, Aguilar et al. 1993, Storr-Hansen \& Spliid 1993). The composition and quantity of OCs in animals within a given ecosystem are the result of many factors, including the concentrations of pollutants within an ecosystem, the transport rate of pollutants from the source to the ecosystem, the detoxification and degradation processes the pollutants undergo before they are ingested, and biological factors such as age, reproductive condition, and health (Aguilar 1987). The relative importance of each of these factors may differ from system to system and populations inhabiting different regions may be expected to have qualitatively and quantitatively different $O C$ compositions (Aguilar 1987). Calambokidis (1986), for example, documented significant regional differences in some OC compounds in harbour porpoise blubber samples collected at different locations along the western coast of the United States. Calambokidis \& Barlow (1991) reasoned that such differences could only arise if porpoises in these areas were allopatric. Recently, Aguilar et al. (1993) documented heterogeneities in the OC profiles of female pilot whales (Globicephala melas) from different pods killed around the Faroe Islands and suggested this represented some form of biological or geographical segregation in pilot whale schools.

The objective of this study was to determine if there are systematic differences in the organochlorine contaminant composition of harbour porpoises from 3 areas in the western North Atlantic (Newfoundland, the Gulf of St. Lawrence, and the Bay of Fundy-Gulf of Maine) and to evaluate the practicability of using this information in defining population structure. The concentra- tions and accumulation patterns of OCs in these porpoises have been described previously (Westgate et al. 1997).

\section{METHODS}

Sample collection. All harbour porpoise samples were obtained through the co-operation of national observer programs of commercial gill net fisheries. Between 1989 and 1991 blubber samples were obtained from 188 harbour porpoises killed incidentally in gill net fisheries in the coastal waters of the Avalon Peninsula, Newfoundland, the Gaspé Peninsula, Quebec (Gulf of St. Lawrence), Grand Manan Island, New Brunswick (Bay of Fundy), and Jeffreys Ledge in the Gulf of Maine (Fig. 1). Sample sizes, method of sample collection, and sampling years from each locality are given in Table 1.

Age determination. Ages were obtained by examining dentinal growth layers in decalcified and stained thin-sections of teeth, as recommended by the Oslo Workshop (Bjørge et al. 1995). An age estimate was not available from 1 porpoise from Newfoundland, but the age of this individual was estimated to be 1 yr based on its length (Richardson 1992).

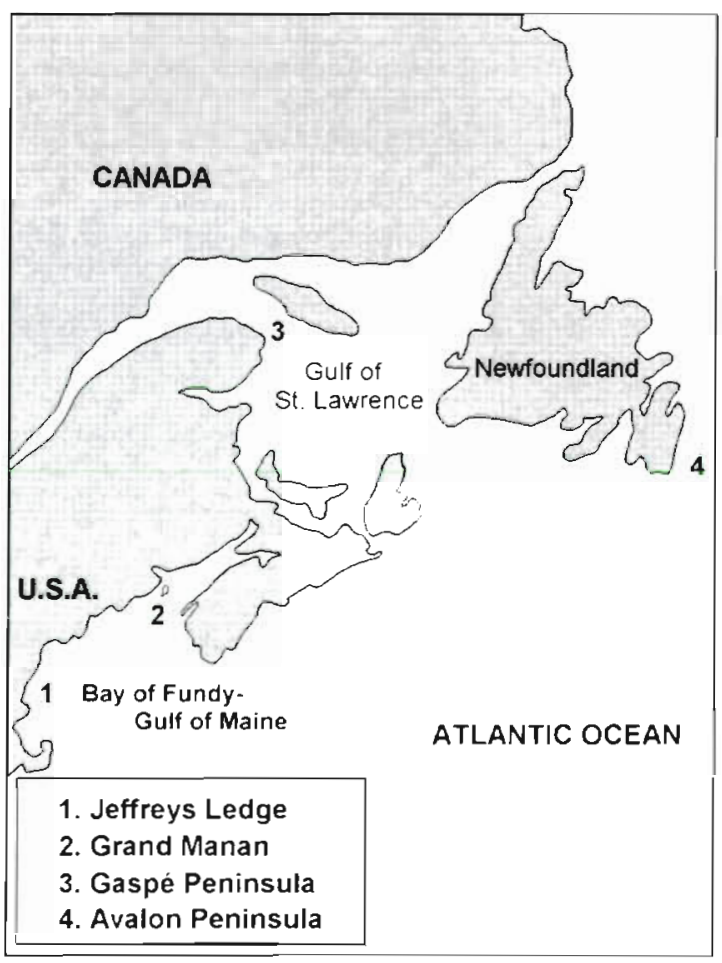

Fig. 1. Northeastern seaboard of North America showing the 4 areas from which harbour porpoise samples were obtained. All samples were collected between 1989 and 1991 from individuals incidentally caught in commercial fisheries 
Organochlorine data. The contaminant concentrations in the blubber of each porpoise were obtained using the methods described by Westgate et al. (1997). All contaminant concentrations were quantified using a gas chromatograph with an ${ }^{63} \mathrm{Ni}$ electron capture detector and are reported as ppm wet weight. Arithmetic means are reported with one standard deviation unless otherwise noted. Total polychlorinated biphenyls ( $\Sigma$ PCBs) were the sum of 68 congeners. Individual PCB congeners (abbreviated as $P$ followed by a number) are numbered according to Ballschmiter \& Zell (1980). Chlorinated bornanes (CHBs) were determined with a single response factor based on a CHB standard (US Environmental Protection Agency repository, Cincinnati, Ohio). Total CHBs ( $\Sigma \mathrm{CHBs}$ ) were the sum of all detected peaks which typically varied between 10 and 14 (abbreviated as $\mathrm{T}$ followed by a number). Total dichloro-diphenyl-trichloroethane (इDDT) included $p, p^{\prime}$-DDT, $o, p$-DDT, $p, p^{\prime}$-dichloro-diphenylethane (DDE), o,p-DDE, $p, p^{\prime}$-dichloro-diphenyl-ethane (DDD) and $o, p$-DDD. Total chlordane ( $\Sigma C H L O R$ ) was the sum of 14 chlordane-related components, including: hepachlor, trans-nonachlor (TNONA), oxychlor (OXYCLR), trans-chlordane (TCHLOR), cis-chlordane (CCHLOR), cis-nonachlor (CNONA), hepachlor epoxide (HEPOX), C, C2/U5, U3, U1, C1A, C3 and C5. Total chlorobenzenes ( $\Sigma \mathrm{CBZs}$ ) was the sum of penta- and hexa-chlorobenzenes. Total hexachlorocyclohexane $(\Sigma \mathrm{HCH})$ was the sum of all 3 hexachlorocyclohexane isomers $(\alpha, \beta, \gamma)$. Dieldrin (DIELD), oxystyrene (OCSTYR) and mirex were also quantified.

Statistical methods. There is little evidence to support the separation of Bay of Fundy and Gulf of Maine porpoises into 2 distinct samples; analysis of mitochondrial DNA documented little genetic variation between these groups (Wang et al. 1996), life history parameters have been shown to be similar (Read \& Hohn 1995) and recent evidence obtained from satellite telemetry (Read \& Westgate 1997) revealed extensive movements between the Bay of Fundy and Gulf of Maine. Thus porpoises from the Bay of Fundy and Gulf of Maine were pooled for all further comparisons.

Two separate analyses (detailed below) were conducted with these data. First, an analysis of covariance (ANCOVA), using age as the covariate, was used to test for differences in 6 families of OCs (CBZs, HCHs, DDTs, CHLORs, PCBs and CHBs) among all the porpoises from the 3 geographic locations. Second, a multivariate analysis was used to test for geographic differences in porpoises from a single reproductive class using a much larger number of individual $O C$ variables. Thus, the former analysis accounted for variation introduced by the large sample size and the latter accounted for variation introduced by the large number of quantified compounds. Statistical analyses were conducted using either SAS (SAS 1989) or SPSS (SPSS 1997) software packages.

Analysis of covariance. Separate analyses were conducted for each sex on porpoises of all ages $(n=188)$. Geographical differences in the concentrations of contaminant groups ( $\Sigma \mathrm{PCB}, \Sigma \mathrm{CHB}, \Sigma \mathrm{DDT}, \Sigma \mathrm{CHLOR}, \Sigma \mathrm{CBZ}$, $\Sigma \mathrm{HCH}$ ) were tested by analysis of covariance using age as the covariate. Frequency distributions of the residuals of the linear models were tested for normality (Shapiro-Wilk test [Zar 1974]) and all distributions were subsequently normalised with a $\log _{e}(x+1)$ transformation. When the assumption of homogeneity of slopes among groups was met (Littell et al. 1991) and the ANCOVA revealed significant differences between locations, 3 pairwise comparisons of least squares means were examined (Newfoundland-St. Lawrence, Newfoundland-Fundy-Maine, Fundy-Maine-St. Lawrence). To decrease the chance of making a Type I error, the alpha level was increased to 0.01 for each pairwise test. In the case where slopes were heterogeneous, Type III sums of squares (corresponding to Yates' weighted squares of means analysis) were calculated and examined for location differences (Littell et al. 1991).

Multivariate analysis. This analysis was limited to male and female porpoises less than 4 yr of age $(n=$ 100 ) because no significant differences in OC concentrations have been documented among these age and sex classes (Westgate et al. 1997).

To remove the influence of absolute concentration, the OC data from each porpoise were normalised to sum to 100 . Following the recommendations of Schwartz \& Stalling (1991), the data were further 
transformed using $\log _{e}(x+1)$ to reduce the influence of closure. Finally, each variable was scaled so as to have a mean of 0 and a variance of 1 .

Up to 99 individual $O C$ compounds were quantified in harbour porpoise blubber. Of these, 48 compounds were excluded from the multivariate analysis because they were found to be non-normal after transformation or were below the level of detection in some samples $\left(<0.01 \mu \mathrm{g} \mathrm{g}^{-1}\right)$. We acknowledge that elimination of the last group weakens the power of the analysis, but this was necessary to avoid problems associated with the statistical analysis of concentrations below the level of detection.

Principal components analysis (PCA) was used to reduce the final data set of 51 variables to a new series of linear combinations (principal components) (Tabachnik \& Fidell 1996). Although combining all 3 localities within a single PCA may confound the intra-specific variation, this technique allowed for the original data set to be reduced to a smaller, more manageable number of variables. To simplify the final interpretation, the varimax rotation was used and only those principal components with eigenvalues greater than 1.0 were extracted. This technique is suited to chemometric comparisons and is described by Schwartz \& Stalling (1991) and Storr-Hansen \& Spliid (1993).

A discriminant analysis (DA), which utilised the principal components as input variables, was used to determine if the group centroids (multivariate means) were significantly different. This descriptive facet of
DA was also used to evaluate which discriminant functions (or sets of predictor variables) contributed to group differences. In addition, the DA was used to reclassify each porpoise into 1 of the geographic groups based on the discriminant functions (Tabachnick \& Fidell 1996). The adequacy of the re-classification was determined by the percentage of correct classifications, assuming that there was an equal probability $(33 \%)$ of being classified into any of the 3 groups by chance alone. Classification rates substantially greater than $33 \%$ for any given group would indicate that the discriminant functions were satisfactory for predicting group membership. The reclassification rates were cross-validated by classifying each porpoise based on the functions derived from all porpoises other than that porpoise.

Age distributions. Contaminant levels in harbour porpoises are related to age (Westgate et al. 1997), so age distributions from each location were compared pairwise by sex, using the Kolmogorov-Smirnov test (Zar 1974).

\section{RESULTS}

\section{Age distributions}

The age distributions of the male and female samples were not significantly different among regions (for bivariate test) nor were the age distributions of the

Table 2. Results of the ANCOVA of the 6 families of contaminants recorded in male harbour porpoise blubber samples from the Bay of Fundy-Gulf of Maine, Gulf of St. Lawrence and Newfoundland. The equation of each regression line is shown with age as the independent and compound as the dependent variables. Means ( \pm SD) and ranges of the contaminant levels are also shown.

Significant differences among regions are indicated; areas followed by the same letters are not significantly different.

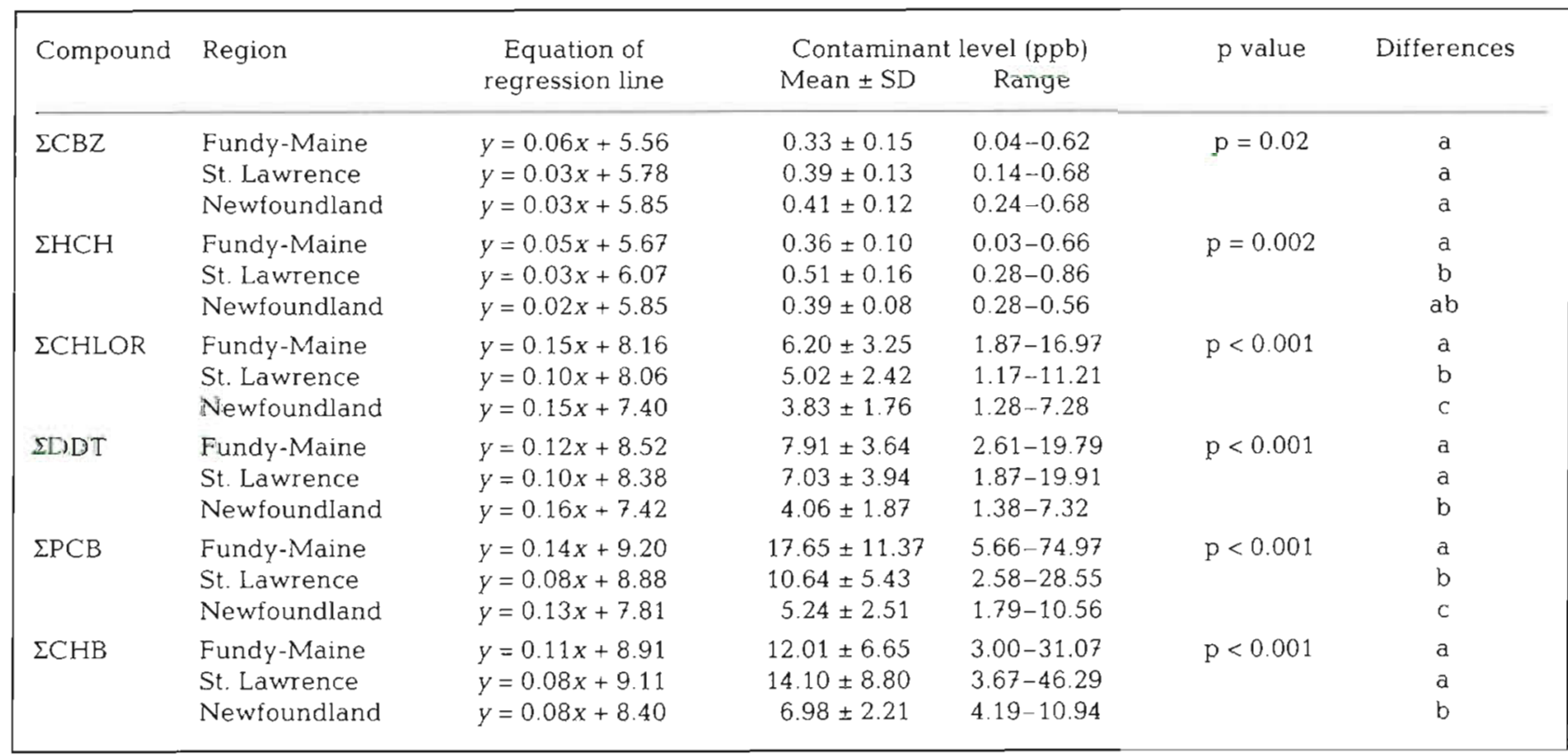


immature porpoises different among regions (for multivariate test).

\section{Analysis of covariance}

The assumption of homogeneity of slopes between geographic groups was satisfied in all cases $(p=0.09$ to 0.80 ), with the exception of $\mathrm{\Sigma HCH}$ and $\mathrm{\Sigma CHB}$ in female porpoises $(p<0.05)$. There were significant geographic differences for all contaminants except $\Sigma C B Z$ in males $(p=0.20)$ and $\Sigma C B Z(p=0.24), \Sigma H C H(p=0.09)$ and $\Sigma C H B(p=0.6)$ in females (Tables $2 \& 3)$. In the male sample, all slopes were significantly positive (Table 2) while in female porpoises all slopes, except $\Sigma$ CHB for St. Lawrence, were significantly negative (Table 3 ).

\section{Males}

The results of pairwise comparisons of adjusted means of organochlorine concentrations among locations for males are presented in Table 2. Both FundyMaine and St. Lawrence males had significantly higher levels of $\Sigma$ CHLOR, $\Sigma D D T, \Sigma P C B$ and $\Sigma C H B$ than animals from Newfoundland. Fundy-Maine males had significantly higher levels of LCHLOR and $\Sigma$ PCB than individuals from the St. Lawrence and St. Lawrence males had significantly higher levels of $\Sigma \mathrm{HCH}$ than males from Fundy-Maine.
Females

The results of pairwise comparisons of adjusted means of organochlorine concentrations among locations for females are presented in Table 3. Females from Fundy-Maine had significantly higher levels of $\mathrm{PCB}$ than females from both St. Lawrence and Newfoundland. Total DDT levels were significantly higher in Fundy-Maine and St. Lawrence females than those from Newfoundland. Total CHLOR values were significantly higher in Fundy-Maine than Newfoundland females.

\section{Multivariate analysis}

Principal components analysis

Preliminary results indicated that it was appropriate to proceed with the PCA: the Kaiser-Meyer-Olkin measure of sampling adequacy was high (0.802), there were sizeable correlations among the original variables, there were low correlations in the residuals matrix, and there were several original variables which loaded highly on each function (Tabachnick \& Fidell 1996). Four OCs (P85, P151, P172, U3) were eliminated from the PCA due to low communalities. A low communality score suggests that the inclusion of these variables would not assist in describing the variation present in the data due to low correlations with

Table 3. Results of the ANCOVA of the 6 families of contaminants recorded in female harbour porpoise blubber samples from the Bay of Fundy-Gulf of Maine, Gulf of St. Lawrence and Newfoundland. The equation of each regression line is shown with age as the independent and compound as the dependent variables. Means ( \pm SD) and ranges of the contaminant levels are also shown.

Significant differences among regions are indicated; areas followed by the same letters are not significantly different

\begin{tabular}{|c|c|c|c|c|c|c|}
\hline \multirow[t]{2}{*}{ Compound } & \multirow[t]{2}{*}{ Region } & \multirow{2}{*}{$\begin{array}{l}\text { Equation of } \\
\text { regression line }\end{array}$} & \multicolumn{2}{|c|}{ Contaminant level (ppb) } & \multirow[t]{2}{*}{$p$ value } & \multirow[t]{2}{*}{ Differences } \\
\hline & & & Mean \pm SD & Range & & \\
\hline$\Sigma C B Z$ & $\begin{array}{l}\text { Fundy-Maine } \\
\text { St. Lawrence } \\
\text { Newfoundland }\end{array}$ & $\begin{array}{l}y=-0.21 x+5.90 \\
y=-0.17 x+6.03 \\
y=-0.43 x+6.48\end{array}$ & $\begin{array}{l}0.24 \pm 0.16 \\
0.29 \pm 0.15 \\
0.34 \pm 0.24\end{array}$ & $\begin{array}{l}0.02-0.64 \\
0.04-0.62 \\
0.05-0.81\end{array}$ & $\mathrm{p}=0.24$ & $\begin{array}{l}\mathrm{a} \\
\mathrm{a} \\
\mathrm{a}\end{array}$ \\
\hline$\Sigma \mathrm{HCH}$ & $\begin{array}{l}\text { Fundy-Maine } \\
\text { St. Lawtence } \\
\text { Newfoundland }\end{array}$ & $\begin{array}{l}y=-0.11 x+5.94 \\
y=-0.07 x+6.07 \\
y=-0.29 x+6.38\end{array}$ & $\begin{array}{l}0.29 \pm 0.13 \\
0.36 \pm 0.13 \\
0.36 \pm 0.19\end{array}$ & $\begin{array}{l}0.07-0.69 \\
0.11-0.59 \\
0.11-0.68\end{array}$ & $\mathrm{p}=0.09$ & $\begin{array}{l}\mathrm{a} \\
\mathrm{a} \\
\mathrm{a}\end{array}$ \\
\hline$\Sigma \mathrm{CHLOR}$ & $\begin{array}{l}\text { Fundy-Maine } \\
\text { St. Lawrence } \\
\text { Newfoundland }\end{array}$ & $\begin{array}{l}y=-0.10 x+8.45 \\
y=-0.06 x+8.14 \\
y=-0.20 x+8.16\end{array}$ & $\begin{array}{l}3.75 \pm 1.78 \\
3.33 \pm 1.85 \\
2.73 \pm 1.79\end{array}$ & $\begin{array}{l}0.85-7.29 \\
0.85-7.90 \\
0.81-5.61\end{array}$ & $p=0.02$ & $\begin{array}{c}\mathrm{a} \\
\mathrm{ab} \\
\mathrm{b}\end{array}$ \\
\hline$\Sigma \mathrm{DDT}$ & $\begin{array}{l}\text { Fundy-Maine } \\
\text { St. Lawrence } \\
\text { Newfoundland }\end{array}$ & $\begin{array}{l}y=-0.9 x+8.82 \\
y=-0.03 x+8.44 \\
y=-0.18 x+8.23\end{array}$ & $\begin{array}{l}5.53 \pm 2.49 \\
4.84 \pm 2.76 \\
3.13 \pm 2.27\end{array}$ & $\begin{array}{l}1.38-12.43 \\
1.16-13.18 \\
1.04-7.55\end{array}$ & $p<0.001$ & $\begin{array}{l}\mathrm{a} \\
\mathrm{a} \\
\mathrm{b}\end{array}$ \\
\hline$\Sigma P C B$ & $\begin{array}{l}\text { Fundy-Maine } \\
\text { St. Lawrence } \\
\text { Newfoundland }\end{array}$ & $\begin{array}{l}y=-0.07 x+9.49 \\
y=-0.05 x+8.95 \\
y=-0.16 x+8.67\end{array}$ & $\begin{array}{r}11.34 \pm 4.76 \\
7.41 \pm 3.90 \\
5.49 \pm 4.37\end{array}$ & $\begin{array}{l}1.95-24.95 \\
1.43-16.66 \\
1.44-14.16\end{array}$ & $\mathrm{p}<0.001$ & $\begin{array}{l}a \\
b \\
c\end{array}$ \\
\hline$\Sigma \mathrm{CHB}$ & $\begin{array}{l}\text { Fundy-Maine } \\
\text { St. Lawrence } \\
\text { Newfoundland }\end{array}$ & $\begin{array}{l}y=-0.11 x+9.18 \\
y=0.01 x+8.97 \\
y=-0.23 x+8.97\end{array}$ & $\begin{array}{l}8.09 \pm 4.92 \\
9.80 \pm 6.41 \\
5.49 \pm 2.96\end{array}$ & $\begin{array}{l}0.97-21.56 \\
1.52-26.71 \\
1.78-10.75\end{array}$ & $p=0.19$ & $\begin{array}{l}\mathrm{a} \\
\mathrm{a} \\
\mathrm{a}\end{array}$ \\
\hline
\end{tabular}




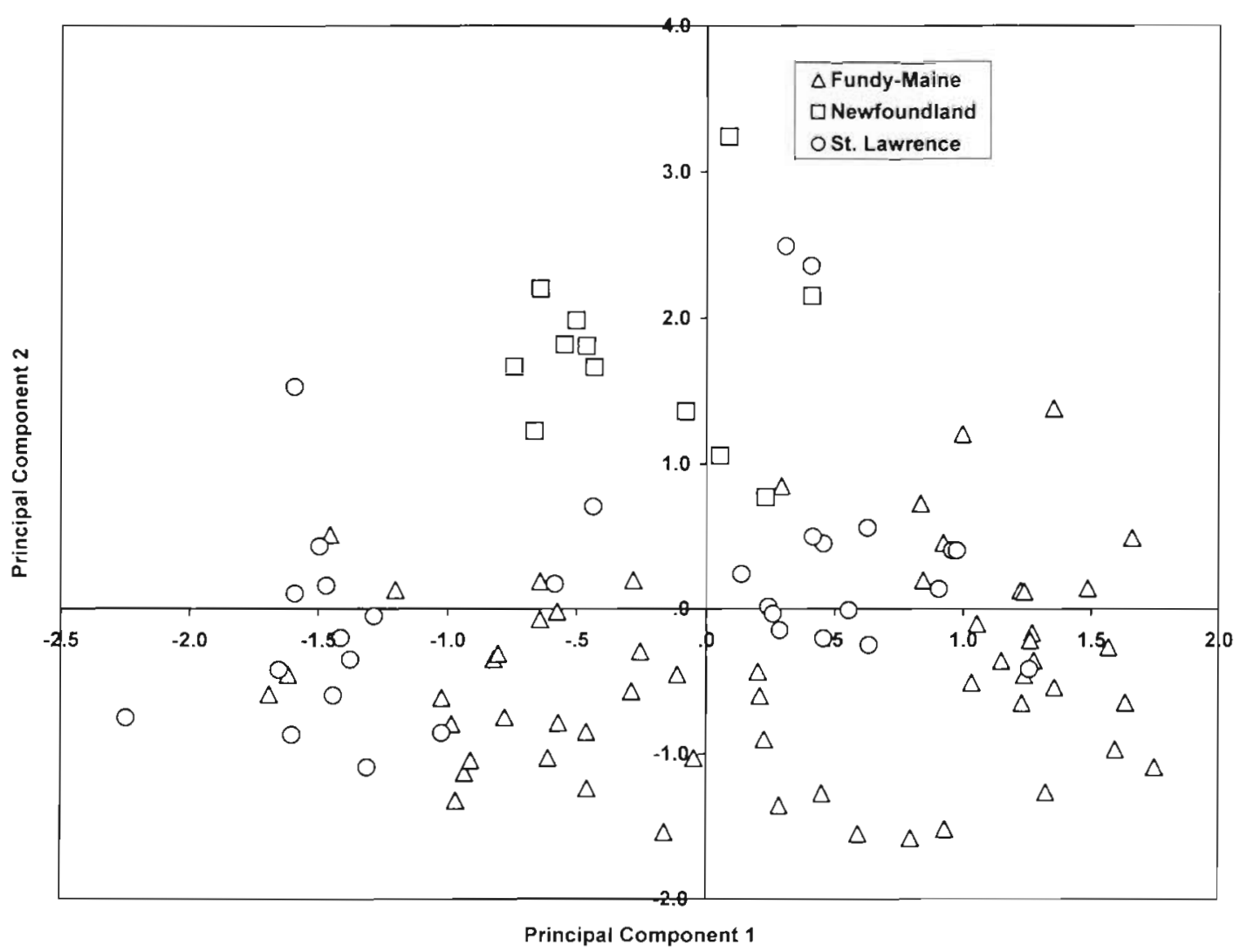

Fig. 2. Principal component scores for harbour porpoises from the Bay of Fundy-Gulf of Maine $(\Delta)$, Newfoundland ( $\square$ ), and the Gulf of St. Lawrence $(0)$, plotted on principal components 1 and 2

other original variables and with resulting principal components (Tabachnick \& Fidell 1996). The ensuing analysis was conducted on the remaining 47 OCs.

The first 9 principal components (PCs) extracted had eigenvalues greater than 1.0 and accounted for $85 \%$ of the total variation present (Table 4 ). A scatterplot of individual porpoises on the first 2 principal components is shown in Fig. 2. There were 5 OCs which correlated highly with PC1 and can be considered as defining. P149 and P95 had strong positive loadings (correlations), and T2, T12, and $\mathrm{BHCH}$ had strong negative locdings (Fig. 3, Table 4). Additional variables with high loadings are shown. in Table 4. Individuals scoring high on PC1 (those toward the right of the scatterplot) had high levels of organochlorines which correlated positively with PC1. Individuals scoring low on PC1 had high levels of organochlorines correlating negatively with PC1. Four OCs had high positive loadings on $\mathrm{PC} 2(\alpha \mathrm{HCH}, \gamma \mathrm{HCH}$, OCSTYR, HCBZ) and can be considered defining for that factor. Additional variables with high loadings are shown in Table 4. Each additional factor can be best defined by those original variables with the highest loadings

\section{Discriminant analysis}

There were significant differences among the group centroids on both discriminant functions (Wilks' Lambda; $p<0.001$ ), suggesting the geographic groups were distinguishable based on OC levels (Fig. 4). Discriminant function 1 (DF1) was highly correlated with $\mathrm{PC} 2$, suggesting that the separation among the groups on DF1 was due to those OCs associated with PC2. Discriminant function 2 was positively correlated with PCs 1 and 8, and negatively correlated with PC6 suggesting that the separation of the groups on DF2 was due to OCs associated with those principal components.

The scatterplot shows the largest degree of separation among groups is along DF1 (Fig. 4), and is primarily due to those OCs which were associated with $\mathrm{PC} 2$ (Table 4). In general, the Newfoundland group had comparatively high levels of $\alpha \mathrm{HCH}, \gamma \mathrm{HCH}$, OCSTYR, HCBZ, OPDDE, P44, and TCHLOR, and comparatively low levels of P183, P138, P52, P170, P180, and P187. The Fundy-Maine group showed the opposite composition (low levels of $\alpha \mathrm{HCH}, \gamma \mathrm{HCH}$, OCSTYR, HCBZ, OPDDE, P44, and TCHLOR, and comparatively high levels of P183, P138, P52, P170, P180, and P187), while 


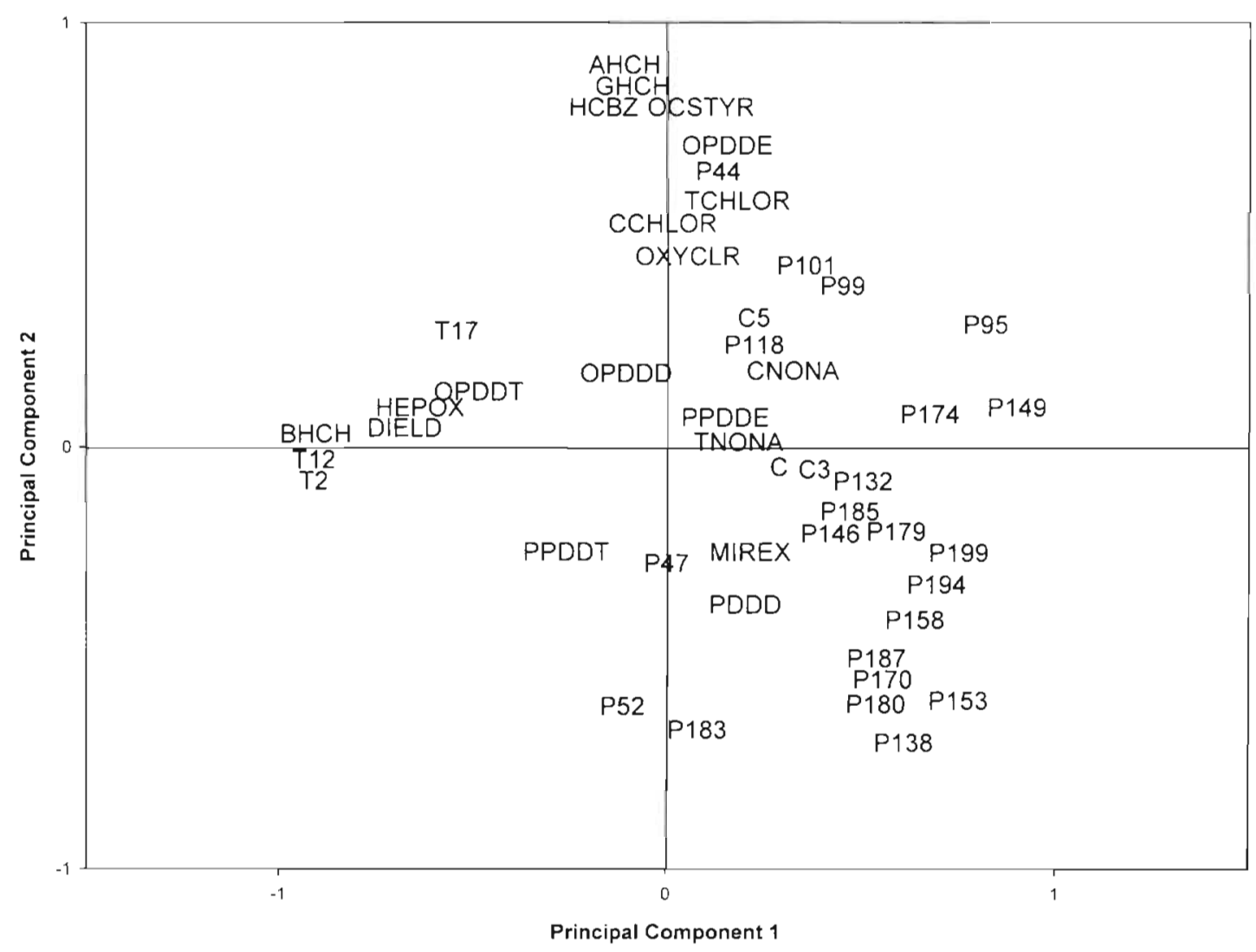

Fig. 3. Loading plot showing the distribution of the original 47 variables plotted on principal components 1 and 2

the Gulf of St. Lawrence showed an intermediate composition.

PC6 had a strong negative correlation with DF2 despite encompassing very little of the original variation $(3.8 \%)$. This suggested that the differences observed on DF2 were due mainly to PC6 (P146, P179, and P185). The high position of the Newfoundland group centroid and the negative correlation that exists between PC6 and DF2 implied that Newfoundland porpoises had the lowest levels of these 3 PCBs, with intermediate and high levels observed in FundyMaine and Gulf of St. Lawrence porpoises respectively.

Although most of the original variation present in the data was attributed to PC1 $(30.5 \%)$, PC1 was less important in group discrimination because its correlation with DF2 was not particularly high (Table 5). Fourteen of the original 47 variables were highly correlated with PC1, but the unimportance of PC1 in the discrimination of groups suggested that these OCs are not particularly important in group discrimination.

A posteriori classification was $93 \%$ for the Bay of Fundy-Gulf of Maine group, $87 \%$ for Gulf of St. Lawrence, and $83 \%$ for Newfoundland (Table 6). Cross-validation rates were similar to the original clas- sification rates (Table 6). Individuals from FundyMaine and Newfoundland were never misidentified as each other. Porpoises from Fundy-Maine and the Gulf of St. Lawrence were occasionally misclassified as each other, as were individuals from the Gulf of St. Lawrence and Newfoundland. This suggests that the Fundy-Maine group has a suite of OC levels recognisably different from those found in Newfoundland porpoises. Although the Gulf of St. Lawrence individuals can be reliably classified, this group appears to be somewhat intermediate to the Fundy-Maine and Newfoundland groups. The high classification rates in each group, combined with significant differences on both discriminant functions suggests that the principal components groupings of the data are reliable for group discrimination of OC levels based on geographic location

\section{DISCUSSION}

The results of both analyses showed that the contaminant profiles of Newfoundland harbour porpoises were markedly different from both St. Lawrence and Bay of Fundy-Gulf of Maine animals. A lesser but sig- 
Table 4. Principal component loadings for each original organochlorine (OC) contaminant measured in harbour porpoises from the Bay of Fundy-Gulf of Maine, Newfoundland, and the Gulf of St. Lawrence. Only the strongest loadings are given, and OCs are grouped according to the principal component with which they had the strongest correlation (indicated by the loading value). Eigenvalues (Eigen.) and percent of total variation (\% var.) are also given for each principal component. See 'Methods: organochlorine data' for contaminant definitions. Cont. $=$ contaminant

\begin{tabular}{|c|c|c|c|c|c|c|c|c|c|}
\hline Cont. & \multicolumn{4}{|c|}{ PC1 PC2 PC3 PC4 } & $\mathrm{PC} 5$ & 5 PC6 & $6 \mathrm{PC7}$ & PC8 & $\mathrm{PC9}$ \\
\hline P149 & \multicolumn{4}{|c|}{0.898} & & & & & \\
\hline P95 & \multicolumn{4}{|c|}{0.817} & & & & & \\
\hline P194 & \multicolumn{4}{|c|}{0.694} & & & & & \\
\hline P153 & \multicolumn{4}{|c|}{0.693} & & & & & \\
\hline P199 & \multicolumn{4}{|c|}{0.677} & & & & & \\
\hline $\mathrm{P} 174$ & \multicolumn{4}{|c|}{0.675} & & & & & \\
\hline P158 & \multicolumn{4}{|c|}{0.638} & & & & & \\
\hline P132 & \multicolumn{4}{|c|}{0.504} & & & & & \\
\hline $\mathrm{T} 2$ & \multicolumn{4}{|c|}{-0.910} & & & & & \\
\hline $\mathrm{T} 12$ & \multicolumn{4}{|c|}{-0.910} & & & & & \\
\hline $\mathrm{BHCH}$ & \multicolumn{4}{|c|}{-0.905} & & & & & \\
\hline DIELD - & \multicolumn{4}{|c|}{-0.676} & & & & & \\
\hline HEPOX - & \multicolumn{4}{|c|}{-0.636} & & & & & \\
\hline T17 & \multicolumn{4}{|c|}{-0.542} & & & & & \\
\hline $\mathrm{AHCH}$ & \multicolumn{4}{|c|}{0.880} & & & & & \\
\hline $\mathrm{GHCH}$ & \multicolumn{4}{|c|}{0.835} & & & & & \\
\hline OCSTYR & \multicolumn{4}{|c|}{0.831} & & & & & \\
\hline $\mathrm{HCBZ}$ & \multicolumn{4}{|c|}{0.827} & & & & & \\
\hline OPDDE & & 0.69 & & & & & & & \\
\hline P44 & & 0.64 & & & & & & & \\
\hline TCHLOR & & 0.55 & & & & & & & \\
\hline P183 & & -0.66 & & & & & & & \\
\hline P138 & & -0.64 & & & & & & & \\
\hline P52 & & -0.61 & & & & & & & \\
\hline P170 & & -0.61 & & & & & & & \\
\hline P180 & & -0.60 & & & & & & & \\
\hline P187 & & -0.58 & & & & & & & \\
\hline TNONA & & & 0.90 & & & & & & \\
\hline CNONA & & & 0.82 & & & & & & \\
\hline OXYCLR & & & 0.75 & & & & & & \\
\hline $\mathrm{C} 3$ & & & 0.59 & & & & & & \\
\hline P99 & & & -0.66 & & & & & & \\
\hline P101 & & & -0.65 & & & & & & \\
\hline P118 & & & -0.53 & & & & & & \\
\hline OPDDD & & & & 0.913 & & & & & \\
\hline OPDDT & & & & 0.664 & & & & & \\
\hline $\mathrm{C5}$ & & & & & 0.800 & & & & \\
\hline CCHLOR & & & & & 0.695 & & & & \\
\hline P179 & & & & & & 0.680 & & & \\
\hline P185 & & & & & & 0.630 & & & \\
\hline P146 & & & & & & 0.594 & & & \\
\hline PPDDE & & & & & & & -0.81 & & \\
\hline PDDD & & & & & & & -0.71 & & \\
\hline PPDDT & & & & & & & -0.50 & & \\
\hline P47 & & & & & & & & 0.592 & \\
\hline $\mathrm{C}$ & & & & & & & & 0.520 & \\
\hline MIREX & & & & & & & & & 0.833 \\
\hline Eigen. & 10.9 & $\begin{array}{ll}9 & 8.9\end{array}$ & 5.1 & 3.1 & 2.9 & 2.5 & 2.4 & 2.2 & 2.0 \\
\hline$\%$ var. & 23.2 & 219.0 & 10.8 & 6.7 & 6.1 & 5.2 & 5.2 & 4.6 & 4.2 \\
\hline
\end{tabular}

nificant level of distinction was also present between porpoises from St. Lawrence and Fundy-Maine areas. The differences in contaminant profiles of harbour porpoises from the 3 regions presented here supports Gaskin's (1984) hypothesis that porpoises from Newfoundland, Gulf of St. Lawrence and Bay of FundyGulf of Maine comprise separate sub-populations.

\section{Bivariate analysis}

The similarities in the slopes of the regression lines for male and female harbour porpoises indicate that the bioaccumulation processes are similar in all 3 regions. This agrees with previous studies of harbour porpoises (Gaskin et al. 1971, 1976, 1983, Westgate et al. 1997), which showed that male harbour porpoises tend to accumulate OCs throughout their lives whereas levels in females tend to decrease, presumably due to the losses incurred transplacentally to the foetus and through lactation. These findings also indicate that contaminant concentrations change gradually with age in harbour porpoises and dramatic or unpredictable fluctuations are generally not observed.

The contaminant composition recorded in harbour porpoises from Newfoundland, St. Lawrence, and Bay of Fundy-Gulf of Maine were similar (see Westgate et al. 1997) but levels in both male and female porpoises showed marked differences between the locations. The concentrations of most OCs in harbour porpoises from Newfoundland were significantly lower than in porpoises from the other 2 regions. Of the 6 contaminant groups examined, 4 were significantly lower in Newfoundland males (Table 2) and 3 in Newfoundland females (Table 3). The greatest differences were found in levels of $\Sigma$ PCBs in male porpoises which were $70 \%$ and $51 \%$ lower in Newfoundland than in Fundy-Maine

Table 5. Discriminant function (DF) loadings for each principal component extracted for harbour porpoises from the Bay of Fundy-Gulf of Maine, Newfoundland, and the Gulf of St. Lawrence. Principal components are ordered according to the absolute magnitude of the correlation with the 2 discriminant functions

\begin{tabular}{|lrr|}
\hline & DF 1 & DF 2 \\
\hline PC2 & 0.480 & 0.313 \\
PC3 & 0.129 & -0.027 \\
PC4 & 0.116 & -0.113 \\
PC6 & 0.031 & -0.736 \\
PC8 & -0.110 & 0.251 \\
PC1 & -0.134 & 0.240 \\
PC7 & 0.143 & 0.191 \\
PC5 & 0.084 & -0.107 \\
PC9 & -0.063 & 0.088 \\
\hline
\end{tabular}




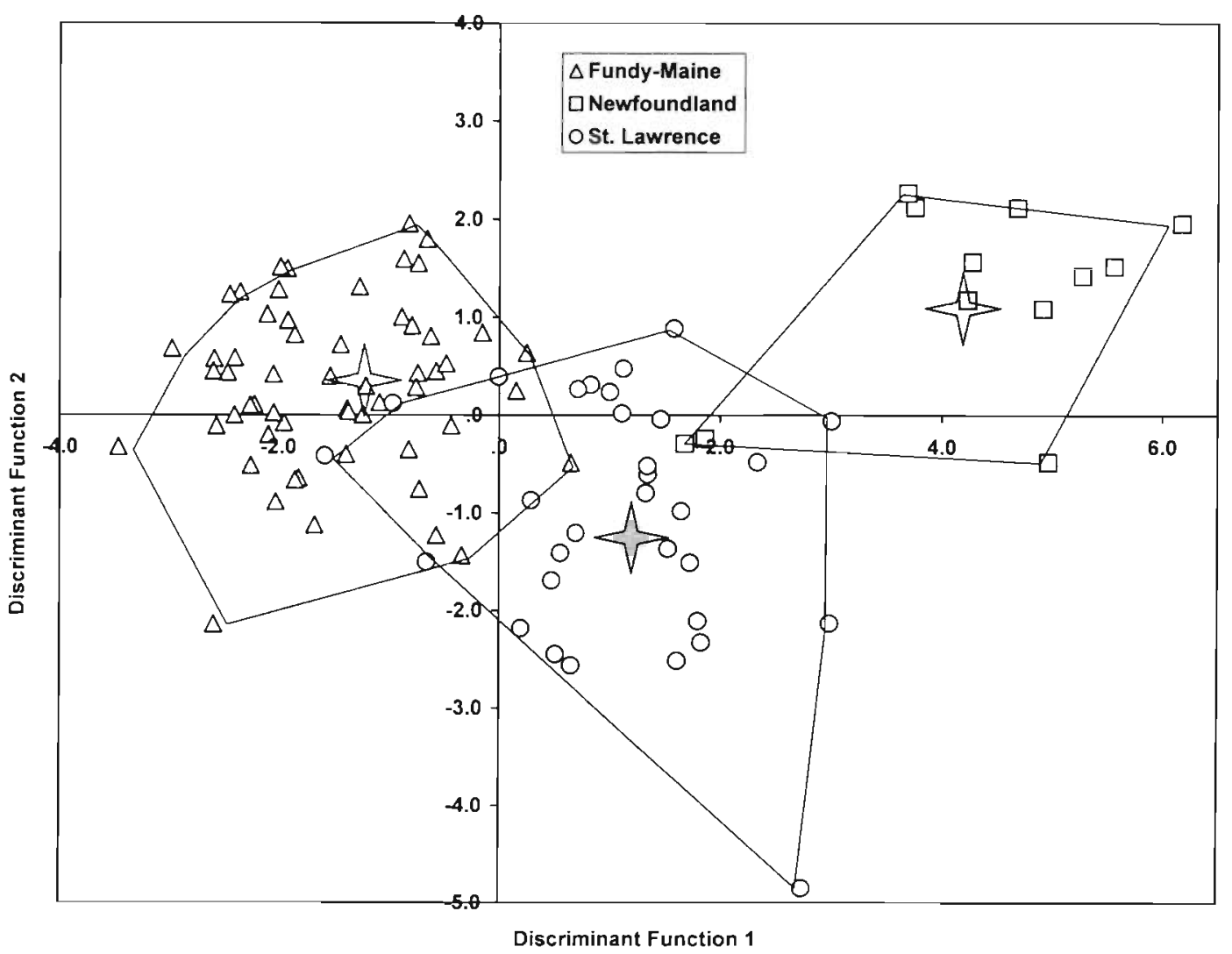

Fig. 4. Discriminant function scores for harbour porpoises from the Bay of Fundy-Gulf of Maine ( $\Delta$ ), Newfoundland ( $\square$ ), and the Gulf of St. Lawrence (O), plotted on discriminant functions 1 and 2. Group centroids are indicated with the grey stars. Lines were plotted around each group to aid in visualisation

and St. Lawrence animals, respectively. Total CHLOR, ¿DDT and $\Sigma$ CHB were all between $24 \%$ and $70 \%$ lower in males from Newfoundland than in males from the other 2 areas (Table 2). In the female sample, levels

Table 6. Classification results from the discriminant analysis of harbour porpoises from the Bay of Fundy-Gulf of Maine, Newfoundland, and the Gulf of St. Lawrence. The left column indicates the original group while the top row indicates the predicted group. Percentage of porpoises classified into a group are given, with the absolute number of porpoises in parentheses. Correct classifications are italicized and misclassifications are not italicized

\begin{tabular}{|lcccc|}
\hline & $\begin{array}{c}\text { Fundy- } \\
\text { Maine }\end{array}$ & $\begin{array}{c}\text { Newfound- } \\
\text { land }\end{array}$ & $\begin{array}{c}\text { Gulf of } \\
\text { St. Lawrence }\end{array}$ \\
\hline $\begin{array}{l}\text { Original count } \\
\text { Fundy-Maine }\end{array}$ & $93 \%(53)$ & $0 \%(0)$ & $7 \%(4)$ \\
Newfoundland & $0 \%(0)$ & $83.3 \%(10)$ & $16.7 \%(2)$ \\
Gulf of St. Lawrence & $9.7 \%(3)$ & $3.2 \%(1)$ & $87.1 \%(27)$ \\
Cross-validated count & & & \\
Fundy-Maine & $91.2 \%(52)$ & $0 \%(0)$ & $8.8 \%(5)$ \\
Newfoundland & $0 \%(0)$ & $83.3 \%(10)$ & $16.7 \%(2)$ \\
Gulf of St. Lawrence & $12.9 \%(9)$ & $3.2 \%(1)$ & $83.9 \%(26)$ \\
\hline
\end{tabular}

of $\Sigma$ CHLOR and SDDT were also significantly lower in Newfoundland compared to Fundy-Maine porpoises (Table 3). $\Sigma$ PCB levels showed the most striking differences, with Newfoundland females having levels that were $52 \%$ lower than Fundy-Maine and 26\% lower than St. Lawrence. $\Sigma$ PCBs were also significantly different between Fundy-Maine and St. Lawrence, with the latter group being $35 \%$ lower than the former.

Levels of $\Sigma \mathrm{CBZ}$ and $\Sigma \mathrm{HCH}$ were present in much lower concentrations than were the other compounds (Tables $2 \& 3$ ). With the exception of the significantly higher levels of $\mathrm{\Sigma HCH}$ found in St. Lawrence males, there was little geographic variation observed in the concentration of these compounds. This observation fits well with predictions of the cold condensation effect of semi-volatile organics (Wania \& Mackey 1993). Volatile compounds like HCHs and CBZs tend to be more evenly distributed worldwide while deposition of less volatile compounds (e.g. PCBs, DDT) appears to be more rapid close to their sources (e.g. urban and intense agricultural areas of the USA). Similar homogeneities in the levels of these compounds have been observed in arctic whales (Muir et al. 1990) and seals (Weis \& Muir 1997). 


\section{Multivariate analysis}

The results of the discriminant analysis confirmed the presence of geographic variation in OCs among immature porpoises. Verifying the analysis of covariance, the Newfoundland porpoises had lower levels of PCBs, specifically P52, P138, P146, P170, P179, P180, $\mathrm{P} 183$, and P185. Porpoises from Newfoundland were the most distinct (Fig, 4), and the positioning of the St. Lawrence and Fundy-Maine groups was consistent with higher levels of contaminants in porpoises from these 2 regions (Tables $2 \& 3$ ).

High reclassification rates for each geographic group implied that sub-population identity can be reliably predicted based on the organochlorine discriminant functions (Table 6). Porpoises from the Gulf of St. Lawrence were occasionally misclassified as either Fundy-Maine or Newfoundland, suggesting that the St. Lawrence group had an organochlorine profile intermediate to the other 2 groups. Fundy-Maine and Newfoundland porpoises were never misclassified as each other, suggesting their organochlorine profiles were distinct.

\section{Possible sources of geographic variation}

Differences in contaminant concentrations can arise from 1 or more of the following factors: (1) animals sampled are of dissimilar age, reproductive status or health, (2) animals are feeding on prey items that are differentially contaminated, and hence are accumulating xenobiotics at varying rates, and (3) animals and their prey are inhabiting waters that have different contaminant compositions due to differences in proximity to pollution sources.

\section{Condition of porpoises}

Variation in age, reproductive status, and condition did not account for the differences observed in this study. Although samples were comprised of different relative proportions of reproductive classes, these were not significantly different with respect to age distributions, making the composition of each sample, as a whole, similar. Marine mammals in varying degrees of body condition can have different OC levels because, as their blubber fat is mobilised or deposited, pollutants can concentrate or dilute (Aguilar 1985 . Addison 1989). We assume that most porpoises examined in this study were in good body condition because of the random nature of the sampling process (i.e. animals captured in gill nets). In an examination of 212 porpoises killed in groundfish gill nets, Read (1990) found all to be in good body condition. In addition, all porpoises examined in this study had similar percent lipid values in their blubber (Newfoundland $88.7 \pm$ $3.2 \%$, St. Lawrence $88.8 \pm 3.1 \%$, Fundy-Maine $88.3 \pm$ $2.6 \%$ ), which varies with condition in other odontocetes (Addison 1989, Aguilar et al. 1992). It is possible that there were more subtle variations in health or condition that were responsible for the observed differences, but in a recent study that examined contaminants, cause of death, and body condition in harbour porpoises from British waters, Kuiken et al. (1994) found that there was no relationship between contaminant levels and cause of death or condition. It would seem unlikely, therefore, that differences in condition contributed to the geographic differences observed here.

\section{Food sources}

Unlike most aquatic organisms that accumulate OCs through bioconcentration and bioaccumulation (Connell 1988), cetaceans acquire over $90 \%$ of their OCs directly from the food they ingest (Aguilar 1987). Therefore, differences in the contaminant composition of harbour porpoises reflect concomitant differences in the prey they consume. Analysis of stomach contents has revealed that the composition of the diets of harbour porpoises from the regions differ. Harbour porpoises from Newfoundland feed primarily on capelin Mallotus villosus (Garry Stenson, Department of Fisheries and Oceans, St. John's, pers. comm.). The diet of porpoises from the Bay of Fundy-Gulf of Maine is primarily Atlantic herring Clupea harengus (Recchia \& Read 1989), and St. Lawrence porpoises feed on a mixture of both capelin and herring (Fontaine et al. 1994 b). Assuming that there are few inter-regional differences in feeding rates (Innes et al. 1987), it follows that contaminant levels in the prey of the Newfoundland porpoises are lower than those in St. Lawrence and Fundy-Maine. It is not clear to what extent contaminant levels differ between capelin and herring; however, given that both fishes feed at the same trophic level on similar items (Jangaard 1974, Scott \& Scott 1988) and both have similar, although seasonally variable, fat contents (herring 5-15\% [Leim 1957]; capelin $1-23 \%$ [Winters 1970]), the presumed lower contaminant loads found in Newfoundland capelin likely reflect a lower degree of contamination in the Newfoundland ecosystem rather than trophic or physiological differences in these prey species. One potential bias is the fact that we know very little about how the diet of Newfoundland harbour porpoises varies on an annual basis. Therefore, the lower levels that were recorded in the blubber of the Newfoundland por- 
poises could be the direct reflection of their exploiting prey items during the fall and winter that have a lower position on the food web. Seasonal changes in the diet of Fundy-Maine porpoises have been recently documented (Gannon et al. 1997) and they show a shift in the relative importance of the most common prey species (Atlantic herring, silver hake Merluccius bilinearis, pearlsides Maurolicus weitzmani] rather than a shift toward new prey species. It is not known how quickly blubber, and the contaminants therein, turn over in marine mammals. If these turnover processes were on the order of years, as would seem from the trends shown by Westgate et al. (1997), then the profile in a given porpoise would be an integration of contaminants ingested over the entire year rather than those from the season of sampling, thereby reducing the possible influence of seasonal shifts in diet. Seasonal variation in the levels of contaminants in harbour porpoises and their prey is an area that warrants further investigation.

Pollution pathways and proximity to sources

Anthropogenic chemicals enter marine ecosystems through several major pathways: via gas absorption directly into surface waters, via wet and dry deposition from the atmosphere as rain and particulate matter, and directly as dissolved and adsorbed particles in freshwater runoff and effluent discharges (Clark 1992). The movement and pathways of organochlorine pollutants into the 3 regions is complex and not well understood, so it is difficult to say with certainty what sources and transport processes are responsible for the contaminants found in these environments. It seems reasonable, however, to assume that the relative influence of aerial and runoff sources both currently and historically are responsible for the differences observed between locations.

The majority of organochlorines in the marine environment around Newfoundland are thought to have originated in more industrialised regions of Canada and the United States because Newfoundland lacks extensive agricultural and industrial development (Wells \& Rolston 1991). Most organochlorines have low vapour pressures so that significant quantities volatilise from the sites of application and storage and once in the atmospheric circulation, can be transported considerable distances (Barrie et al. 1992, Norstrom \& Muir 1994). It has been suggested that there is a positive net transport from low to high latitudes because volatile contaminants would have a tendency to condense in colder temperate and arctic regions (Ottar 1981. Wania \& Mackey 1993). Aerial transport would also be a major source of OCs for the Gulf of St.
Lawrence and Bay of Fundy-Gulf of Maine ecosystems as these regions are situated such that they receive air masses that have previously moved over the major agricultural and industrial regions in North America (Rapaport \& Eisenreich 1988). In addition, there are also significant direct inputs via discharge from industry, and runoff from agriculture and landfills because the watersheds of the Gulf of St. Lawrence and the Bay of Fundy-Gulf of Maine drain some of the most developed regions of North America (McAdie 1994). Even though most of the OCs in question have been banned or restricted in the United States and Canada, extensive past use coupled with the long half lives of these compounds would mean that there could still be significant flux rates between sediments and water. This could account for the similar levels of PCBs and DDTs in St. Lawrence and Fundy-Maine porpoises.

\section{Comparisons with other studies}

The degree of $O C$ contamination recorded in harbour porpoises from the 3 locations is consistent with other studies which have examined geographical trends in OCs in marine mammals. Generally, marine mammals that inhabit coastal regions closer to industrialised zones have higher levels of contaminants than animals inhabiting more remote environments (Muir et al. 1990, Beck et al. 1994). Calambokidis \& Barlow (1991) measured PCB (representing more chlorinated homologs only), HCB (the dominant component of $\Sigma \mathrm{CBZ}$ ) and DDE contaminant concentrations in 45 harbour porpoises from Washington, Oregon, and California, and reported that $p, p^{\prime}$-DDE levels significantly increased in a north to south gradient. The other 2 compounds did not vary among the 3 sampling locations. Unfortunately, the balance of Calambokidis and Barlow's analysis focused on examining ratios rather than concentrations of contaminants and they did not report age data so it is difficult to compare their results directly with those presented here. The greater degree of differences observed in the present study could reflect different degrees of mixing within east and west coast harbour porpoise populations or differential contaminant gradients along these coasts.

The significantly higher PCB levels recorded in both male and female porpoises from the Bay of Fundy-Gulf of Maine are consistent with the high levels recorded in bottlenose dolphins Tursiops truncatus from the eastern seaboard of the United States (Geraci 1989) and may be indicative of local levels of contamination in the Gulf of Maine. These results are also in accordance with other studies that have reported contaminant levels in this area. Profiles of PCBs, DDTs, CHBs, HCHs and CBZs examined in 
peat cores from Bar Harbor, Maine, and Forchu, Nova Scotia, indicate higher levels of all contaminants (except CHB, see below) at the Bar Harbor site (Rapaport \& Eisenreich 1988\}.

The differences in the relative composition of contaminant groups are consistent with other studies that examined the relative importance of various $\mathrm{OC}$ contaminants in these regions. Stein et al. (1992) found PCBs to be the dominant contaminant in 3 harbour porpoises from the Gulf of Maine. The Newfoundland results are similar to those obtained in studies of whitebeaked dolphins Lagenorhynchus albirostris and pilot whales from Newfoundland, in which $\Sigma$ CHBs were the most prevalent contaminants (Muir et al. 1988). Total CHBs were also the dominant contaminant documented in peat cores sampled along the Northeast coast of Nova Scotia as well as in rainfall sampled around the Avalon Peninsula (Bidleman et al. 1981).

\section{Implications for structure below the population level}

There is a critical need to define harbour porpoise population structure in the Northwest Atlantic because of the high levels of incidental take in gill net fisheries. Identification of sub-populations is necessary for management and conservation. Recently it has been proposed that investigations into structure below the population level should include observations and measurements of distributional, population response, phenotypic, and genotypic data that imply or measure the degree of allopatry and genetic uniqueness (Dizon et al. 1992). Our report provides new information that infers distributional differences for porpoises in the Northwest Atlantic.

Harbour porpoise population structure as indicated by organochlorine contaminant differences is consistent with population structure inferred from restriction fragment length polymorphism analysis of the mitochondrial DNA. molecule. Wang et al. (1996) found significant differences in female mitochondrial DNA haplotype frequencies among these same regions for each pairing of the geographic groups. When males were included in the analysis, Bay of Fundy-Gulf of Maine haplotype frequencies were found to differ significantly from the other 2 geographic areas, but the Gulf of St. Lawrence and Newfoundland were not significantly different from each other. Based on these results, Wang et al. (1996) suggested the observed differences indicated that female porpoises are more philopatric than males, while males from the Gulf of St. Lawrence and Newfoundland may undergo dispersal. The temporal resolution of genetic techniques is limited by both population size and the rate of dispersal (Dizon et al. 1997). In fact, movement of one individual per generation between sub-populations is thought to be enough to prevent the detection of quantifiable genetic differences (Hoelzel \& Dover 1991). Examination of contaminant levels in putative sub-populations, however, integrates differences that have accumulated over much shorter periods (lifetime) and are therefore more likely to reflect actual ecological differences. These differences in temporal scales of resolution (genetics = evolutionary time; contaminants = ecologi cal time) likely account for the minor differences observed between the previous genetic and present contaminant studies.

The close agreement between the genetic and contaminant evidence strongly supports the putative subpopulation structure proposed by Gaskin (1984). One limitation in the use of contaminants to discriminate stocks is the obvious lack of direct association between contaminants and genetics (see Aguilar 1987). Subpopulations that appear allopatric on the basis of distinctive contaminant burdens could experience considerable gene flow, especially if they are sympatric during the breeding season. For example it is possible that male porpoises could be moving between Newfoundland and St. Lawrence waters to breed. Despite similarities in genetic profiles (Wang et al. 1996), the significant differences in contaminants between male porpoises from St. Lawrence and Newfoundland waters means that they experience different ecological regimes during much of the year. This, taken together with the significant differences between females porpoises from the 2 regions in both contaminant loads and mitochondrial DNA fragments, underscores the need to consider porpoises from these 2 areas as separate for the purposes of management and conservation. Investigation into the structure of the St. Lawrence and Newfoundland sub-populations using more sensitive genetic tools (microsatelites or sequencing techniques) would be a useful test of this hypothetical population structure.

Different ecosystems often have different contaminant levels because of the complex way xenobiotics interact with the environment. Recording contaminant levels in any animal population represents a powerful tool for examining regional ecological differences. This technique also provides a valuable tool for examining the sub-structure of animal populations, especially when used in concert with other techniques. Contaminant burdens present in any animal are constrained simply by where the animal lives and feeds and can therefore be more sensitive than other genetically based techniques. Providing a reasonable sample size can be obtained and any potentially confounding effects ruled out, contaminant based population structure analysis, like that presented here, is worthy of further investigation. 
Acknowledgements. We thank all the Canadian and American fishermen whose co-operation was instrumental in obtaining porpoise carcasses for sampling. Samples were kindly provided by G. Stenson and S. Richardson (Newfoundland), M. Kingsley, P. M. Fontaine, A. Evely, and M. Kozicki (Gulf of St. Lawrence), and J. Nicholas, A. Read and G. Early (Gulf of Maine). Collection of the Bay of Fundy samples was carried out with the assistance of personnel at the Grand Manan Whale and Seabird Research Station. M. Segstro was instrumental in all aspects of the organochlorine analysis. This manuscript was improved by help and comments from D. Johnston, H. Koopman, D. Lavigne and A. Read. This work would not have been possible without the support of D. Muir (Department of Fisheries and Oceans, Freshwater Institute), D. Gaskin (University of Guelph) and M. Kingsley (Department of Fisheries and Oceans, Maurice Lamontagne Institute). Funding was provided by the Wildlife Toxicology Fund of World Wildlife Fund Canada, Greenpeace Canada, and the Natural Sciences and Engineering Council of Canada A5863 operating grant to D. Gaskin, as well as the Department of Fisheries and Oceans, the St. Lawrence Action Plan of the Department of Fisheries and Oceans (Maurice Lamontagne Institute) and Environment Canada (St. Lawrence Centre) to M. Kingsley and D. Muir

\section{LITERATURE CITED}

Addison RF (1989) Organochlorines and marine mammal reproduction. Can J Fish Aquat Sci 46:360-368

Aguilar A (1985) Compartmentation and reliability of sampling procedures in organochlorine pollution surveys of cetaceans. Residue Rev 95:91-114

Aguilar A (1987) Using organochlorine pollutants to discriminate marine mammal populations: a review and critique of methods. Mar Mamm Sci 3:242-262

Aguilar A, Borrell A, Calzada N, Grau E (1992) Body fat reserves in striped dolphins examined during the western Mediterranean die-off. In: Pastor X, Simmonds $M$ (eds) Proc Mediterranean Striped Dolphin Mortality Int Workshop, 4-5 November 1991, Palma de Mallorca. Greenpeace Mediterranean Project, Greenpeace, Madrid, p $47-52$

Aguilar A, Jover L, Borrell A (1993) Heterogeneities in organochlorine profiles of Faroese long-finned pilot whales: indication of segregation between pods? In: Donovan GP, Lockyer $\mathrm{CH}$, Martin AR (eds) Biology of Northern Hemisphere Pilot Whales. Rep Int Whal Comm Spec Issue $14: 351-358$

Ballschmiter K, Zell M (1980) Analysis of polychlorinatedbiphenyls (PCB) by glass capillary gas chromatography. Composition of technical aroclor and clophen-PCB mixtures. Z Anal Chem 302:20-31

Barrie LA, Gregor D, Hargrave B, Lake R, Muir D, Shearer R, Tracey B, Bidleman T (1992) Arctic contaminants: sources, occurrence and pathways. Sci Tot Environ 122:1-74

Beck GG, Smith TG, Addison RF (1994) Organochlorine residues in harp seals, Phoca groenlandica, from the Gulf of St. Lawrence and Hudson Strait: an evaluation of contaminant concentrations and burdens. Can J Zool 72 $174-182$

Bidleman TF, Christensen EJ, Billings WN, Leonard R (1981) Atmospheric transport of organochlorines in the North Atlantic gyre. J Mar Res 39:443-464

Bjørge A, Hohn AA, Lockyer C, Schweder T (1995) Summary report from the harbour porpoise age determination workshop, Oslo, 21-23 May 1990. In: Bjorge A, Donovan GP (eds) Biology of the Phocoenids. Rep Int Whal Comm Spec Issue 16:477-545

Bravington MV, Bisack, KD (1996) Estimates of harbour porpoise bycatch in the Gulf of Maine sink gillnet fishery, 1990-1993. Rep Int Whal Comm 46:567-574

Calambokidis J (1986) Chlorinated hydrocarbons in harbour porpoise from Washington, Oregon, and California: regional differences in pollutant ratios. NMFS Admin Rep LJ-86-35C, Southwest Fisheries Center, La Jolla, CA, p $1-29$

Calambokidis J, Barlow J (1991) Chlorinated hydrocarbon concentrations and their use for describing population discreteness in harbour porpoises from Washington, Oregon, and California. In: Reynolds JE, Odell DK (eds) Marine mammal strandings in the United States. NOAA (Natl Ocean Atmos Adm) Tech Rep NMFS (Natl Mar Fish Serv) $98, \mathrm{p} 101-110$

Clark RB (1992) Marine pollution. Oxford University Press, Oxford

Connell DW (1988) Bioaccumulation behavior of persistent organic chemicals with aquatic organisms. Rev Environ Contam Toxicol 101:117-154

Dizon AE, Lockyer C, Perrin WF, Demaster DP, Sisson J (1992) Rethinking the stock concept: a phylogeographic approach. Conserv Biol 6:24-36

Dizon AE, Perrin WF, Amos W, Baker CS, Chivers SJ, Costa AS, Curry BE, Gaggiotti O, Hoelzel AR, Hofman R, LeDuc RG, Loughlin TR, Lux CA, O'Corry-Crowe GM, Rosel PE, Rosenberg A, Scribner KT, Taylor BL (1997) Report of the workshop In: Dizon AE, Chiver SJ, Perrin WF (eds) Molecular genetics of marine mammals. Soc Mar Mammalogy Spec Publ 3, Lawrence, KS, p 3-48

Fontaine PM, Barrette C, Hammill MO, Kingsley MC (1994a) Incidental catches of harbour porpoise (Phocoena phocoena) in the Gulf of St. Lawrence and the St. Lawrence estuary Quebec, Canada. In: Perrin WF, Donovan GP, Barlow J (eds) Gillnets and cetaceans. Rep Int Whal Comm Spec Issue 15:159-163

Fontaine PM, Hammill MO, Barrette C, Kingsley MC (1994b) Summer diet of the harbour porpoise (Phocoena phocoena) in the estuary and the Northern Gulf of St. Lawrence. Can J Fish Aquat Sci 51:172-178

Gannon DP, Craddock JE, Read AJ (1997) Autumn food habits of harbor porpoises, Phocoena phocoena, in the Gulf of Maine. Fish Bull 96:428-437

Gaskin DE (1984) The harbour porpoise Phocoena phocoena (L.): regional populations, status, and information on direct and indirect catches. Rep Int Whal Comm 34: $569-586$

Gaskin DE (1992) Status of the harbour porpoise, Phocoena phocoena, in Canada. Can Field Nat 106:36-54

Gaskin DE, Holdrinet M, Frank R (1971) Organochlorine pesticide residues in harbour porpoises from the Bay of Fundy region. Nature 223:499-500

Gaskin DE, Holdrinet M. Frank R (1976) DDT residues in blubber of harbour porpoise Phocoena phocoena (L) from eastern Canadian waters during the 5 year period 1969-1973. Mammals in the seas. FAO Fish Ser No 5, 4: $135-143$

Gaskin DE, Frank R, Holdrinet M (1983) Polychlorinated biphenyls in harbour porpoises Phocoena phocoena (L) from the Bay of Fundy, Canada and adjacent waters, with some information on chlordane and hexachlorobenzene levels. Arch Environ Contam Toxicol 12:211-219

Geraci JR (1989) Clinical investigation of the 1987-88 mass mortality of bottlenose dolphins along the U. S. central and south Atlantic coast. Report to the National Marine Fish- 
eries Service, the Office of Naval Research and the Marine Mammal Commission, NMFS, Silver Spring, MD, p 1-63

Hoelzel AR, Dover GA (1991) Molecular genetic ecology. IRL Press, Oxford

Innes S, Lavigne DM, Earle WM, Kovacs KM (1987) Feeding rates of seals and whales. J Anim Ecol 56:115-130

IWC (International Whaling Commission) (1994) Part of appendix G: report of the sub-committee on small cetaceans. Rep Int Whal Comm 45:173-176

Jangaard PM (1974) The capelin (Mallotus villosus): biology, distribution, exploitation, utilization, and composition. Bull Fish Res Board Can 186:1-70

Jefferson TA, Curry B (1994) A global review of porpoise (Cetacea: Phocenidae) mortality in gillnets. Biol Conserv 67:167-183

Kuiken T, Bennett PM, Allchin CR, Kirkwood JK, Baker JR, Lockyer CH, Walton MJ, Sheldrick MC (1994) PCBs, cause of death and body condition in harbour porpoises (Phocoena phocoena) from British waters. Aquat Toxicol 28:13-28

Leim AH (1957) Fatness of herring in Canadian Atlantic waters. In: Leim AH (ed) Report of the Atlantic herring investigation committee. Bull Fish Res Board Can 111. $177-184$

Lien J (1987) Incidental catch of harbour porpoise (Phocoena phocoena) in the waters off Newfoundland and Labrador: Some estimates based on scanty data and a request for further study. CAFSAC WP/87/168, Canadian Atlantic Fisheries Scientific Advisory Committee, St. John's, Newfoundland, $\mathrm{p} 1-6$

Littell RC, Freund RJ, Spector PC (1991) SAS system for linear models, 3rd edn. SAS Institute Inc, Cary, NC

McAdie HG (1994) Atmospheric deposition to the Gulf of Maine. Interim report August 1994, International Joint Commission, Ottawa, Ontario

Muir DCG, Wagemann R, Grift NP, Norstrom RJ, Simon $M$, Lien J (1988) Organochlorine chemical and heavy metal contaminants in white-beaked dolphins (Lagenorhynchus albirostris) and pilot whales (Globicephala melaena) from the coast of Newfoundland, Canada. Arch Environ Contam Toxicol 17:613-629

Muir DCG, Ford CA, Stewart REA, Smith TG, Addison RF, Zinck ME, Béland P (1990) Organochlorine contaminants in belugas, Delphinapterus leucas, from Canadian waters. In: Smith TG, St. Aubin D, Geraci JR (eds) Advances in research on the beluga whale, Delphinapterus leucas. Can Bull Fish Aquat Sci Spec Issue 224:165-190

Norstrom RJ, Muir DCG (1994) Chlorinated hydrocarbons in arctic marine mammals. Sci Tot Environ 154:107-128

Ottar B (1981) The transfer of airborne pollutants to the Arctic region. Atmos Environ 15:1439-1445

Rapaport RA, Eisenreich S (1988) Historical atmospheric inputs of high molecular weight chlorinated hydrocarbons to the eastern North Atlantic. Environ Sci Technol 22: 931-940

Read AJ (1990) Estimation of body condition in harbour porpoises, Phocoena phocoena. Can J Zool 68:1962-1966

Read AJ, Hohn AA (1995) Life in the fast lane: the life history of harbour porpoises from the Gulf of Maine. Mar Mamm Sci 11:423-440

Read AJ, Westgate AJ (1997) Monitoring the movements of harbour porpoises (Phocoena phocoena) with satellite telemetry. Mar Biol 130:315-322

Editorial responsibility: Otto Kinne (Editor).

Oldendorf/Luhe, Germany
Recchia CA, Read AJ (1989) Stomach contents of harbour porpoises, Phocoena phocoena (L.), from the Bay of Fundy. Can J Zool 67:2140-2146

Richardson SF (1992) Growth and reproduction in the harbor porpoise, Phocoena phocoena (L.), from eastern Newfoundland. MSc thesis, Memorial University, St. John's, NF

SAS Institute Inc (1989) SAS/STAT user's guide, version 6, 4th edn. SAS Institute Inc, Cary, NC

Schwartz TR, Stalling DL (1991) Chemometric comparison of polychlorinated biphenyl residues and toxicologically active polychlorinated biphenyl congeners in the eggs of Forster's terns (Sterna fosteri). Arch Environ Contam Toxicol 20:183-199

Scott WB, Scott MG (1988) Atlantic fishes of Canada. University of Toronto Press, Toronto

SPSS Inc (1997) SPSS Base 7.5 for Windows, user's guide. SPSS, Chicago, IL

Stein JE, Tilbury KL, Brown DW, Wigren CA, Meador JP, Robisch PA, Chan S, Varanasi U (1992) Intraorgan distribution of chemical contaminants in tissues of the harbour porpoise (Phocoena phocoena) from the northwest Atlantic. NOAA (Natl Ocean Atmos Admin) Tech Mem NMFS (Natl Mar Fish Serv)-NWFSC-3

Storr-Hansen E, Spliid H (1993) Coplanar polychlorinated biphenyl levels and patterns and the identification of separate populations of harbour seals (Phoca vitulina) in Denmark. Arch Environ Contam 24:44-58

Tabachnick BG, Fidell LS (1996) Using multivariate statistics, 3rd edn. HarperCollins College publishers, New York

Trippel EA, Wang JY, Strong MB, Carter LS, Conway JD (1996) Incidental mortality of harbour porpoise (Phocoena phocoena\} by the gill-net fishery in the lower Bay of Fundy. Can J Fish Aquat Sci 53:1294-1300

Wang JY, Gaskin DE, White BN (1996) Mitochondrial DNA analysis of harbour porpoise, Phocoena phocoena, subpopulations in North American waters. Can J Fish Aquat Sci 53:1632-1645

Wania F, Mackey D (1993) Global fractionation and cold condensation of low volatility organochlorine compounds in polar regions. Ambio 22:10-17

Weis IM, Muir DCG (1997) Geographical variation of persistent organochlorine concentrations in blubber of ringed seal (Phoca hispida) from the Canadian Arctic: univariate and multivariate approaches. Environ Pollut 96:321-333

Wells PE, Rolston SJ (1991) Health of our oceans. A status report on Canadian marine environmental quality. Conservation and protection, Environment Canada, Ottawa

Westgate AJ, Muir DCG, Gaskin DE, Kingsley MCS (1997) Concentrations and accumulation patterns of organochlorine contaminants in the blubber of harbour porpoises, Phocoena phocoena, from the coast of Newfoundland, the Gulf of St. Lawrence and the Bay of Fundy/Gulf of Maine. Environ Pollut 95:105-119

Winters GH (1970) Biological changes in coastal capelin from the overwintering to the spawning condition. J Fish Res Board Can 27:2215-2224

Woodley TH, Read AJ (1991) Potential rates of increase of a harbour porpoise (Phocoena phocoena) population subjected to incidental mortality in commercial fisheries. Can J Fish Aquat Sci 48:2429-2438

Zar JH (1974) Biostatistical analysis. Prentice-Hall Inc, Englewood Cliffs, NJ

Submitted: April 23, 1998; Accepted: October 12, 1998

Proofs received from author(s): January 25, 1999 